\title{
Frank Scott and the Canadian Literary Renaissance
}

\section{by Leon Edel}

In this revised text of the first Frank Sott Memorial Lecture established by McGill's libraries, the alltbor deals with the late dean of the Faculty of Law who was a poet, a man of law, and a well-known political activist. Recognizing that no single individual ever created a national renaissance, the autbor seeks to show the diversity of Scott's attainments and their influence on Canada's present literary flowering. He sees bim as one of Flaubert's "triple thinkers"-that is an individual possessed of a creative inagination that fed all bis undertakings. His poetry suffused bis daily life and bis legal wisdom, and these qualities figured in the creation of the background and scaffolding for the fertile literary expression now under way in Canada. As poet, be belped unify writers across Canada; as public figure be served on the Massey Commission out of which the Canada Council was created. As an illuminated legal mind, be undertook the defence of the written uord in arguing the Lady Chatterley case before the Supreme Conrt and in defeating also the destructive "padlock law" which sought to fetter freedom of speech and opinion. These actions. carried out with strength, wit and brilliancy gave new force to the place of the writer within the nation who, Scott argued, is entitled to the free exercise as well as economic recognition of the literary profession.

Dans cette version révisée de la première Conférence Frank Scott, cycle institué par les bibliotbèques de l'Université McGill, l'auteur parle du dernier doyen de la facnlté de droit qui était poète, bomme de loi et militant politique connn. Conscient qu'une renaissance nationale n'est jamais le fait d'un seul individu, l'autenr cherche ì illustrer la diversité des réalisations de Sott et leur influence sur l'épanouissement actuel de la littérature an Canada. Il le voit comme l'un des "triple penseurs" de Flaubert, c'est-à-dire comme un être doné d'mne imagination créatrice présente dans tout ce qu'il fait. La poésie imprégnait sa vie de tons les jours et son savoir d'bomme de loi; ces qualités ont d'ailleurs contribué à tisser la toile de fond de l'expression littéraire fertile que connait actuellement le Canada et à lui donner naissance. En tant que poète, il a contribué à mnifier les écrivains d'un océan à l'antre; en sa qualité d'bomme public, il a participé anx travanx de la Commission royale d'enquête sur l'avancement des arts, lettres et sciences au Canada (Massey), qui a donné naissance au Conseil des Arts du Canada. Brillant bomme de loi, il a défendn l'acte littéraire en plaidant la cause de Lady Chatterly devant la Cour suprême et en faisant clébouter la destructrice "loi du cadenas" qui cherchait à restreindve la liberté d'expression et d'opinion. Ses prises de position fermes, intelligentes et brillantes ont contribué à renforcer la place de l'écrivain an Canada. Scott soutenait que celui-ci avait droit à la liberté d'expression et à la reconnaissance économique de la profession d'écrivain.

I deeply appreciate the invitation from McGill's libraries to deliver the first memorial lecture on the singular figure who was a part of my early life at this university and who became, in a very remarkable way, a part of Canada's national life. Frank Scott was involved during all his years with Canadian writing and especially poetry. His career as a poet, his need to give cadenced utterance to his daily life, may have seemed marginal to those who observed him because he took up the law and with high distinction served the political life of the nation as well. We know there was a period when he worked 


\section{Frank Scott and the Canadian Literary Renaissance}

for the United Nations. Later, returning, he became Dean of Law at McGill. During the greater part of this century he fought, by means of the word and with his intellectual power, the continuing struggle for human rights and freedoms in Canada.

Toward the end of his life he assembled his collected poems. The wider public discovered that behind the major role he played in the creation of Canada's third political party, behind his concern for the two cultures in Quebec and his great authority in constitutional law, there existed a man of transcendant imagination who expressed himself most characteristically in his poems. We know that writers have become leaders in the national life of many countries. However, in pragmatic America, a continent where the sense of leisure seems never to have properly existed in the ways of Europe, statesmen and politicians have not been noted for their addiction to literature. Lawyers and judges, when inclined to imitate their bewigged contemporaries in Britain (who have been very literary) tend to indulge in extra-legal expression as a hobby-save for the rare figures whose judicial decisions have themselves become a part of national expression.

In the present flowering of EnglishCanadian letters, I have come to see that Frank Scott was a core figure, a kind of founding father in diverse movements that made it possible for our novelists to write works that have given them reputations beyond Canadian frontiers, and enabled its poetry to reach high tide. No single figure can make a literary renaissance. There is always a prevailing spirit of the time, an enveloping atmosphere. The Canadian literary renaissance has been brought to its flowering by many individuals and groups during an epoch in which Canada's nationhood was being tested. The population had to wait for certain evolutionary processes, technological as well as spiritual, to come to full term. Canada was too spacious for community, or as Scott put it in one of his poems "everywhere a huge nowhere," a nation concerned with survival. This comes inevitably before the refinements of civilization. They must arrive in their own good time-as we know from other overcrowded lands, for whom literature, after centuries, became a national collaboration and poetry a national song.

Literature in Canada was lonely. Poets sang to themselves. Fiction had to wait for social density and a longer history. A novel is a narrative of how lives are arranged and lived, and the personal relations that are the tissues of such lives. The hunters and trappers and Indians and Inuit furnished early Canadian themes of the Fenimore Cooper or, say, Ralph Connor, variety. Little use was made of the one-street towns, the russet elevators raising their bulky box-like structures into a wideness of sky, the local churches, and the banksusually the only buidings constructed of stone-in the small towns. And the lost ladies and lost men living in them starved for existence in the more charged and congregated parishes, spending much of the year amid snowdrifts.

Frank Scott, as I say, could not alone have made a hiterary renaissance. He was however in the very thick of its making, an Enlightenment man of our time. His intellectual ancestors were the French citizens who made their revolution and proclaimed the Rights of Man two hundred years ago-a bicentenary in process of celebration-and the early Americans who gave birth to the Declaration of Independence. I think history will regard Scott as a figure composed of their kind of fibre and in some respects the fibre and mind of some of the makers of Canada's Confederation of 1867 .

What do I mean when I speak of the Canadian literary renaissance? I am thinking for example of the novelists we could count on our fingers in earlier years, the best sellers Mazo de la Roche, or Ralph Connor, or Morley Callaghan in Toronto or Hugh MacLennan in Montreal, or the satire and slapstick of Stephen Leacock's tales of small town life-he was very much with us during my time at McGill. We look around at this hour and start counting in a larger way-Robertson Davies and Margaret Atwood, Mordecai Richler and Mavis Gallant, Margaret Laurence and Alice Munro and Michael Ondaatje and so many others-and we see how numerous our writers have become, how there are new publishers 
Frank Scott and the Canadian Literary Renaissance

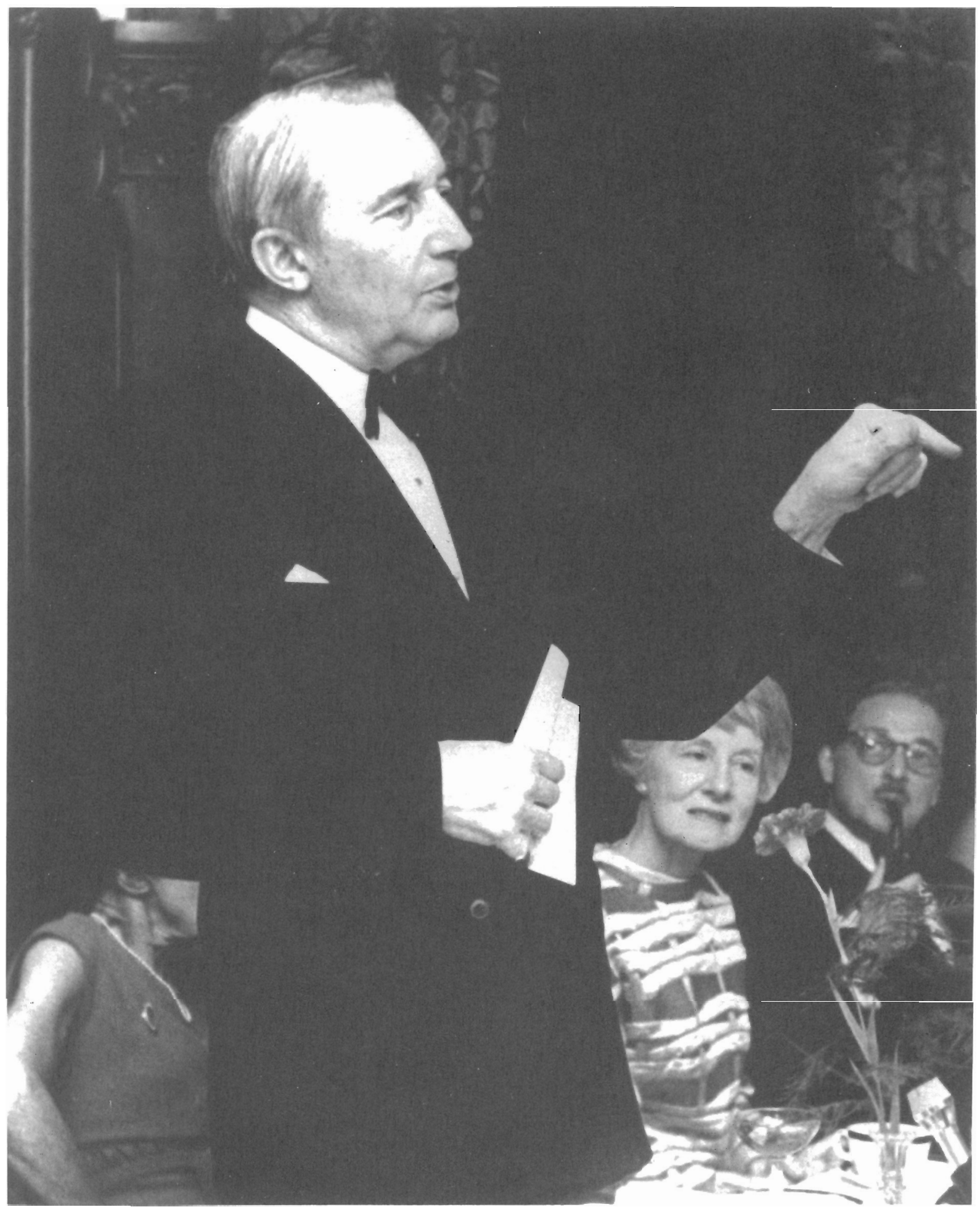

F.R. Scott, ca. 1960. (Photograph by Chris Payne. McGill University Archives.) 


\section{Frank Scott and the Canadian Literary Renaissance}

to publish them and critics like Northrop Frye to write about them. There was always a stream of poetry, at first a thin stream. It struck certain domestic notes, among colonial imitations of the motherland, the mordant lines of Standish O'Grady, or the humane patois of Drummond, the poetry of Lampman and Carman, Roberts and Pratt, and so on. The present poetic outpouring is phenomenal-some 600 poets have sung in Canada between 1960 and the 1980s. They have brought into being 1100 volumes of verse. The statistics need not alarm us. A renaissance provides always a surplus of poets.

To understand Scott's unique role in this flowering we must glance at other forces that made it possible. Perhaps the old army word "logistics" might describe them. When I said that literature was lonely in Canada I meant that on this vast expanse, this sub-continent, "an arena large as Europe," Scott reminded us, from the Cordilleran region to the Laurentian, in the entire physiography of Canada, there lived, when I was a boy in Saskatchewan, only nine million people. Sir John A. Macdonald led the country in achieving Confederation by threading a railroad from the urban east to the Pacific rim-a railroad that ran through wildernesses. Rails however do not tie people together. They only stitch towns across great spaces. The western population lived in railway towns-every few miles a station bearing names that recalled places in the Old World thousand of miles away. We still carried Europe in our memories.

Canada had to wait for the new technologies: the telegraph and the telephone, the Model $T$ and its flamboyant successors, the cement pourers for the highways, the crystal sets and ultimately the electronic revolution. Not least, the airplane. Planes telescope time and space. The political party Scott helped to found, when it took control in Saskatchewan, could use planes to fly doctors and nurses to remote communities and create modern airborne forms of medical insurance. The planes also made it possible, as they multiplied, for poets to journey and give readings. Suddenly there was national mobility. You could climb out of the snowdrifts and soar through cloud lands. The long train journeys, days on trains from Vancouver to Halifax, belonged to the past. Other important unifying forces came, such as the Canada Council. We cannot speak of the literary renaissance without sketching this geography of air and sound waves and electronics, in which Scott participated as a poet, as defender of the word, as member of Royal Commissions, and as a prime fighter against censorship of the imagination.

\section{II}

Frank Scott was born in 1899 in Quebec City. His father, Canon Frederick George Scott, a popular padre with the Canadians on the Western Front during the first war, wrote poetry and practiced a muscular Christianity that included support of labor movements and strikes. In other words he was a radical-as radicalism was defined then in Canada's Conservative establishment. His fifth son, christened Frances Reginald Scott, was educated in Bishop's College and went to Oxford as a Rhodes scholar. Even more than with his father, poetry was for him a natural way of expression, an articulation of personal emotion and belief, a kind of continuing biography of the Self. Exposed to British traditions and the European galleries, he was also caught up in the postwar emotions of 1914-1918. He felt it was time to make the world a place of peace and concord. The young Scott's early diaries suggest, according to Sandra Djwa, his biographer, that he returned to Canada with a Camelot vision. He looked for noble acts and for Sir Galahad!

He got a rude shock. He found shrunken horizons. He discovered the deep-rooted, tight-fisted conservatism of the Canadian oligarchy. Quebec was hedged by religious dogma, Ontario by banks and railroads. He taught at Lower Canada College for a while. By his $26^{\text {th }}$ year he was restless and champing at the bit. In his diary he mused that Napoleon, at age twenty-six, was ready to wage his Italian campaigns, and William Pitt at the same age had been prime minister of England for two years. Here in Canada Scott hadn't even begun a life's work nor was he sure what that work would be. He had, we can see, distinct dreams of glory. Young intel- 
lectuals in Canada who wanted to remake a world outside business usually embraced medicine or law, science, engineering, sometimes theology: the professions gave them a high status and sometimes public life; theology sought active social betterment and God's way to men, and provided a pulpit. Scott chose the McGill law school.

At the university he met A. J. M. Smith-as he formidably signed his poetry. Smith was working for a science degree. His British immigrant parents felt science was safer than poetry. He partially satisfied them with a Bachelor of Science and promptly enrolled in graduate English, writing a thesis on William Butler Yeats and the symbolist movement. In 1925, he convinced the Students' Council that a literary supplement would enhance the McGill Daily. Scott sent in a lively article and some poetry and that was how the two met. Smith's literary supplement was a saucy, highbrow, liberal publication and the university's principal, Sir Arthur Currie, who had led the Canadian army during the war, shuddered. He did not want to tangle with his convervative governing board. The supplement had a short life. The official reason given for its suppression was that the publication was expensive and yielded no advertising. Anyone turning its yellow crumbling pages today would be astonished at the high quality and the power of the sheet's prose and verse, its postwar liberalism, its essays on the future of science, the nature of education, the war poets of England, the future of Canada.

Scott, the political radical, and Smith, the aesthetic radical, joined forces. They decided to publish an independent literary journal. Smith knew that he had created an audience on the campus; Scott was eager to have a medium of literary and political expression. I was then a junior in arts, an immature provincial from Saskatchewan. Smith had met me once or twice when we were reporters downtown and I had contributed a small piece to his supplement. He now invited me to be the new journal's managing editor. Thus began our friendship's which would last all our lives. We easily obtained five hundred one-dollar subscriptions for The McGill Fortnightly Review. This paid for ten issues printed on quality paper, for printing costs were low in those days. We were a success from the start. The McGill establishment, as expected, investigated us for taking the name of McGill for our journal. However the committee it appointed took a liberal view. It decided McGill students were entitled to use the name of their university for a college venture. The principal would have liked us to accept faculty advisers. We declined. One amused member of the committee, who knew Scott's father, poked him in the ribs and said "It's this man who's a dangerous radical." We took the precaution of attaching to our masthead the words "an independent journal of literature and student opinion." That defined us.

For Scott, and indeed for our entire little editorial group, the Fortnigbtly provided a channel for considerable mental and artistic energies, an avenue to poetry and fiction that clamoured to be written and published. It also provided an outlet for Scott's social ideas and his critiques of the Canadian Establishment. His quick and penetrating wit, his philosophical coherence, made him an animating presence at our editorial meetings. He was tall and angular with strong vivid features: like all the young Scotts he had his father's singular beaked nose and he looked out of a single bright questioning eye, having lost the other in a childhood accident. He constantly found Canadian incongruitites and ambiguities in the press and used them with fine effect in both his speaking and writing. Above all he had a personal warmth that nourished us as we gathered in a basement apartment in Atwater avenue, whose ground-level windows gave on huge snowdrifts that brought a white glare into the room. Here we assembled our issues, made up our dummy, sorted the contributions and wrote much of the contents ourselves, often under assumed names. Scott in later years, always spoke of Smith's profound influence on us. Smith opened up "a new poetic country.... My ideas about society, about the capitalist system, about international relations and collective security, brought back from Oxford, were considerably to the left of center: it was the poetry that was lagging, and Arthur supplied the new influence and the motive force." 
That force endured and was sufficient later to spark poetry conferences, new journals and a national literary ferment. Above all, in the future, lay Scott's ability to gather around him other questing Canadian writers and provide a community of endeavour. A dozen years after the Fortnightly published its final issue, Toronto's E. K. Brown, one of Canada's most sensitive critics in the mid-century, spoke of "the Montreal literary movement." It was "an original group" and its journal "far out of the common run...the most interesting that English-Canadian students have ever developed...they were all experimenters, eager to naturalize in Canada the kind of poetry being written by Eliot and Pound." The poetry of the Montreal group, Brown said, and of its disciples and associates, represented "the core of Canadian verse during the past twenty years," that is, from the mid-twenties to the midforties. I think today we might more accurately speak of them as the "Montreal modernists" for there were other modernists elsewhere in Canada. The Montreal strength resided in its having at that time a journal less "collegiate" than it seemed, edited by two sophisticated men in their mid-twenties. The Fortnightly was distinctly addicted to the literary "modern," much more than the Canadian Formm, the national literary journal, founded in Toronto in 1920 for which we would all write in the coming years.

\section{III}

The Fortnightly shut up shop in 1928 when we graduated, Scott in law, while Smith and I received master's degrees. I went off to Paris on a provincial fellowship. Smith received a fellowship in education which took him to Edinburgh. Scott, in Montreal, was a bridge between our original movement and the new journals that began to spring up. He became a part of the Canadian Mercury which sought to be national like the Forum. It was the brainchild of Lew Schwartz, Arts 27, who had been on the McGill Daily with us, and who financed it by taking a job as a social worker and paying most of his salary to the printer. However the 1929 crash and the ensuing depression soon finished it off. Later Scott accepted a position on the McGill law faculty and when Smith and I returned from Europe we had to leave for the United States in search of a livelihood. Canada exported its humanists; it produced more than it could use. And then it still had certain deep-seated prejudices and categories of ethnic preference. Scott, when I came back from Paris, was busy founding the League for Social Reconstruction, a pondered euphemism to avoid any suggestion of Communism. He moved on with this to the founding of the awkwardly named Co-operative Commonwealth Federation (CCF), now the New Democratic Party (NDP).

It was a bleak time. Newer generations, I believe, can't begin to feel the complexities of our existence in the 1930s-the struggle to find a place in the world during the depression, the coming of Hitler, the Spanish Civil War, the general disarray of the democracies, their inability to challenge the fascist readiness to bomb cities and crush democratic institutions and long-held human rights. Scott experienced considerable conflict between his own evolutionary concepts of politics in the face of international gangsterism. He rebelled also against being drawn into a war that British Canada itself did not formally declare. It led him at first to advocate neutrality. However the reality of the bombings of London and the universal collapse of frontiers led him to shift his views. He and Smith had always been pacifists and I shared their feelings. However when I was drafted into the American army in 1943 , I felt that this was a war I wanted to fight. For me it was a war against totalitarian chaos and extinction of all human rights. Scott recognized this in other ways in his search for the spirit of the law, the national binding force of a constitution.

I find among my letters from Scott one which he wrote in answer to condolences I sent him when his father died. I was then in an army camp being readied for the Normandy landings. He urged me to think about returning to Canada after the war "(a) because Canada is moving rapidly ahead, ideologically, while the U.S. isn't (to put it mildly) (b) because we have a group of poets writing here better than anything since the Great Days 
of the Fortnightly and (c) because we'd like to have you back." It was only after the war that I caught up with the new literary history in Canada. Scott, in the midst of his other preoccupations, had helped found a little mimeographed journal that called itself Preview. It offered poetry in the rough, previews of poems that poets might read to one another. New figures had appeared. A vivid Englishman, Patrick Anderson, joined with P. K. Page and others in new movements. Influences from abroad were now Auden and his group and the silver-throated Welsh poet, Dylan Thomas. The war had also politicized many of the poets-some were socialists, others Trotskyites. There were Stalinists, Leninists, middle-roaders, conservatives. Smith was teaching in Michigan and I was a journalist in Manhattan. However we kept returning to Montreal drawn by our ties and attachments. Irving Layton and Louis Dudek had appeared on the scene and reacted against the earlier modernists. They were influenced by poets south of the border, especially William Carlos Williams. Leonard Cohen emerged first as poet and then as troubadour. Layton made noises like a revolutionary eager for a guillotine. In due course, these energies were absorbed in various fusions: Preview and First Statement merged into the Northem Review. Scott was the conciliator and continued to serve on the boards of these journals. There were strong undercurrents-the Fabianism of Scott inevitably did not suit the impatience of the young. Through this effervescent period he remained on the high ground of inquiry into Canada's place and shape in the world. I remember visiting him and his wife Marian Dale in Clarke Avenue in Westmount and encoutering the Laytoniar: presence in the early fifties. Layton felt that Canadian poetry needed to be unbuttoned, like his own work. He seemed unwilling to allow other poets a different sort of vision. Amid rival schools and animated controversies, Scott launched his first volume of verse called Overture.

This is an hour

Of new beginnings, concepts warring for power

Decay of systems - the tissue of art is torn
With overtures of an era being
born.

King Gordon, an old friend of Scott's (son also of the clergyman who had lived in the west and written best-selling adventure novels under the name of Ralph Connor), in later years speculated on the Canadian writers and artists who gathered around the Scotts in Clarke Avenue:

I was trying to discover what single shared idea made them a group. It wasn't literature. It wasn't art. It certainly wasn't socialism. And then it came to me: it was ideas. And the times in which we were living had a lot to do with it. The old orthodoxies were unravelling. The sacred cows were out of their pasture and cluttering the highways. And, as Frank perceived, the Social Register had become a marvellous source of mirth. But beyond the drama and absurdities of a world in change there was the common concern for the human condition, the human tragedy, itself the result of outworn orthodoxies enforced by power.

Beyond this, I believe that what brought the younger poets to Scott, even when they attacked his aristocratic stance, or what seemed to them "aristocratic," but was in reality the deeper reaches of his mind, was that they knew they were in the presence of a man of imagination. It unified his activities; it lit up everything he touched. And the literalists, who add their little sparks to art movements, also recognized this.

In his 1967 essay on Scott "and some of his poems," A. J. M. Smith wrote:

There is hardly a poet in Canada who has not, passing through Montreal, made his pilgrimage to Clarke Avenue, Westmount, and been royally entertained and stimulated with wise and witty talk about poctry and poets; and all of them from the early days of Leo Kennedy, Abe Klein and myself, through the time of Patrick Anderson, John 
Sutherland, P. K. Page and the rest, to the overlapping and heterogeneous groups that might include Louis Dudek, Ralph Gustafson, Irving Layton, Doug Jones and John Glassco, felt the charm, energy and good sense that animate Frank Scott and make him one of the leaders in every group.

We could easily collect a small anthology of memories and tributes to the salon or "poetry center" of Clarke Avenue where Marian, a distinguished painter, presided with grace and reticence, and Scott exchanged ideas and wit with new talents and the barbarians among them. There was no discrimination. Those who professed Walt Whitman's "barbaric yawp" were welcome along with the traditionalists and the more subtle innovators. Doug Jones was among those who said that at Frank Scott's "one felt very much a part of Canadian poetry" and was made acutely aware of "tradition." They read their poems to one another. They read the older poets. When Scott read some of his newer verse they sometimes tore it to pieces. On one occasion, Scott was on the verge of tears, exclaiming that he had perhaps "spread myself too thin." Certainly there were hours when he felt he would rather be professing poetry than spending days in the politics of the CCF or pursing the anomalies and ambiguities of constitutional law.

Leonard Cohen was drawn to Scott. He even enrolled in the law school to hear him develop his legal discussions and theories. He compared this experience to a coral reef-it was as if the law evolved and grew and took on beautiful shapes, metaphors for the human intellect. Scott encouraged him to write, and as with many others of the young around him, recommended him for a Canada Council grant. Scott was always writing letters and recommendations for his younger contemporaries. Cohen described the Clarke Avenue gatherings as "warm and wonderful with a very open fluid atmosphere; lots of fun; drinking; and talking of politics and poetry."

It is always difficult to recover party talk, the jests and irrationalities of a salon. Talk has a way of melting into thin air. In the poems of Scott however one can discover certain illustrations of his capacity for finding high humour in the fatuities of local journalists and editors. He used to make us laugh simply by reading these sentences and giving them proper articulation-an announcement that on Ascension Day elevators in certain buildings would not be ascending; or that there would be no collection of garbage on the day of the Feast of the Immaculate Conception; or that a French restaurant translated deep dish apple pie Tarte aux pommes profondes. When Mackenzie King, who had been a perpetual prime minister during our lives, finally died, Scott brushed aside the pious obituaries with a poem reminding us that King "never let his on the one hand/ know what his on the other hand was doing." Scott was an ideal figure, in his grasp of bilingualism, to serve, as he did, on the Royal Commission on Bilingualism and Biculturalism.

\section{III}

There is another side of Frank Scott to consider in our inquiry, the Scott who rendered services to the arts behind the scenes, behind bureaucracies and legislators who constantly feared enlargement of the nation's humanism. He was one of the original members of the Canadian Writers Committee and similar bodies. More importantly, he was a member of the Massey Commission, that is, the Royal Commission on National Development in the Arts, Letters and Sciences. In one of his eloquent briefs he declared that Canada "must adapt her economy somehow so that artists can earn a living from their work." Speaking to the Commission he said that "the work with which we have been entrusted is concerned with nothing less than the spiritual foundation of our national life." It was out of such long and profound deliberations that the Canada Council was born and we know how significant has been its role in the renaissance. It made possible a much greater diffusion of the written word, gave scholarship a wider terrain, saw to the needs of all the art forms. At various stages $S$ cott also obtained grants from foundations in the United States for such gatherings as the Kingston conference on "The Writer, His Media and the Public." He also 


\section{Frank Scott and the Canadian Literary Renaissance}

helped individual Canadian writers to obtain Rockefeller and Guggenheim grants.

I mention these activities and loyalties, which Scott would dismiss as minor routine elements of his days. They illustrate however the many points at which a pluralistic individual makes himself felt. His activities extended far beyond friendships with poets and novelists. The lists of creative persons Scott knew were long, the coteries he sought out, from the 1920s to the 1970s, represented not only the English and French of Quebec and the old and new schools of Ontario, but the groups of British Columbia, and those that struggled to find a footing in the middle provinces and the Maritimes.

All this was preliminary to the dramatic moment when Scott stepped out of his classroom, borrowed a legal wig, and entered the courts of law to defend the written word. There are always politicians who think of books as objects to be burned, in their compulsion to smother individualism into conformity. Such a man was the dictatorial Maurice Duplessis, provincial premier in Quebec. Behind him stood the hierarchies of the old church, that could not move with the times. Scott fought two historical cases and both reached the Supreme Court of Canada. The first related to the "Padlock Law" of Quebec which Duplessis enacted, a kind of instant device to suppress what he deemed subversion - which meant all activity that did not conform to his curious conception of human rights. It was a morally violent and opressive act. The province padlocked all premises, personal or organizational, suspected of communist gatherings and unorthodox belief. Tenants were thus summarily shut out of their homes; organizational offices were closed down. The padlock was a symbolic buttoning of the mouths of activists in search of social reconstruction. I will not go into the history of the infamous law - it must be well known to this audience. It took the better part of two decades to break the padlocks, to wipe from the statutes of the province the most naked thought-control legislation ever enacted in Canada. In attacking it Scott was fighting also for the rights of Japanese Canadians and for the sect known as Jehovah's Witnesses- their right to exercise their religion which Duplessis and the church sought to extinguish. Scott, in these cases, raised before the Supreme Court the significant question "whether our basic freedom of speech, assembly and the press are at the mercy of the provincial legislature." The Duplessis dictatorship in effect sought to muzzle or frighten public figures, writers, journalists, those who voiced opinions deemed subversive by the political and religious establishment. By the one step, individuals were deprived of their right to trial in open court. No persons were arrested. Premises were simply closed. Or a liquor license was dictatorially cancelled. Step by step, Scott carried this case from defeat to victory.

The second case Scott was prevailed upon to undertake involved D. H. Lawrence's novel Lady Chatterley's Lover. That too, by now, is ancient history. I find myself tempted simply to quote Scott's own light verse recording his experience:

I went to bat for the Lady Chatte Dressed in my bib and gown

The judges three glared down at me

The priests patrolled the town.

My right hand shook as I reached for that book

And rose to play my part.

For out on the street were the marching feet

Of the League of the Sacred Heart.

The reference to "three judges" is to the earlier stages of the case in the provincial courts. Here Scott lost. Ultimately the verdict came from the nine judges of the Supreme Court in Ottawa.

I tried my best with unusual zest,

To drive my argument through.

But I soon got stuck on what rhymes with "muck"

And that dubious work "undue."

So I raised their sights to the Bill of Rights

And cried "Let freedom ring!"

Showed straight from the text that freedom of sex

Was as clear as anything. 


\section{Frank Scott and the Canadian Literary Renaisance}

Scott's feelings of exultation and triumph are reflected in the lively lucidity of these lines. It is characteristic of his light verse, of which we have a great deal, much of it in the anthology The Blasted Pine he compiled with A. J. M. Smith:

Then I plunged into love, the spell that it wove, And its attributes big and bold Till the legal elect all stood erect As my rapturous tale was told.

There are other stanzas equally quotable.

These land mark cases led Scott to think his way through to an ever greater enlargement of the ways in which the rights of man are encapsulated in constitutions: and led too to wider definitions of what these rights should be. They were a part of his faith in the idea of economic as well as political democracy. His lectures to Bar Associations and civic bodies again and again reflect such thoughts. If he could have lived another decade actively, he would have been busy answering the new conservatism that seeks to divest government of the very responsibilities for which it was created. To the Bar Association of Ontario in 1960 Scott said:

Certain human rights...can only be realized through government action...government action means the making and enforcing of laws and we are all accustomed to say that without law there is no liberty... without an unemployment insurance law, or without an old age pension law, or law providing for free universal education, there is no liberty... To deprive people of these essentials to the good life... is to take away human rights.

Thus Scott redefined, in the light of his long nourished beliefs, his conception of what human rights are. These would be labelled communistic or socialistic by the conservatives. Scott however could point to nations that had achieved economic democracy in wide degree without having to move to the extreme left, without having to harness literature to the state, and political thought to
Marxist or other dogma. And in espousing his concept of true freedom, he was driving home some of the principles that made possible, in the realm of the arts, the Canadian literary renaissance, the writer's privilege to work in complete freedom.

\section{V}

It is clear from what I have said that Scott was not an intellectual theorist or a "parlour socialist" as Sir Arthur Currie called him. He was an activist on the Canadian scene. Let us glance at the activist poet in his Collected Poems. He is intensely human. He asks us to laugh with him at fumbling humans faced with designing and building an entire state on one of the world's largest land masses. There is compassion; there is love. The poetry is charged with the imagination of his entire being. We cannot truly divorce the poet from the rest of the man: he used his poetry to illuminate his actions-to try to understand-to articulate-his selfhood and his political and legal ideals. In a lecture during the 1940s to an audience of Canadian artists, Scott said that "the poet can make us aware of life and our place in it...by discovering and expressing the significant and important relationships between man and his heritage." He spoke of art as "the making of something new and true. All life is creation," he said, "and poetry is creation through language." Poetry, he wrote, is unique. "Nothing can take its place," and he added in his punning way, "each verse a universe." It requires "the ability to pull out of the total flow those special elements which are significant." Of course this could be said of the legal and political imagination as well. It is given however to very few men of law or of politics to possess a world-embracing imagination. Scott's volumes of poems that went into the final collection-Overture, Events and Signals, The Eye of the Needle, Signature, The Dance is One-are all of a piece, each a landmark in his own development and that of the Canada of his time. We see in the poems how he continued to open himself up wider and wider to free poetic utterance to the modern forms of poetry. He wrote of troubles and disasters; he envisioned victories of the spirit. 
His eye was quick, his laughter contagious. His journey to the north with the then young Pierre Trudeau, described in "Letters from the Mackenzie River," was a quest to observe and feel the vastness, the extent, of wilderness, its lonely and desolate terrors and beauties. And also to notice the "no trespassing" signs of the oil companies on the lonely expanse. In these poems he reached a still larger dimension of feeling and thought. He now saw archaeology somehow in reverse: not what humans excavate of the past but the unexcavated future.-

\section{Underground \\ In the coins of rocks \\ Cities sleep like seeds}

He sang of all that Canada had been and meant to its struggling people, the bittersweet songs of life and survival, despair and triumph.

This is the poet who quietly and in measured words, helped shape the present literary renaissance. Frank Scott was a singer among singers, a player among players. The public or the private figure, the political Scott or the Dean of the Law School did not conceal the man who told us

$$
\begin{gathered}
\text { In land so bleak and bare } \\
\text { a single plume of smoke } \\
\text { is a scroll of history. }
\end{gathered}
$$

It was in this way that he had first seen the more settled and creative part of Canada. The emptiness could be filled with song, his songs and others, and with stories and with his and others' presence. Unplanned, unmapped, the renaissance was long prepared. The buried seeds, in their proper time, sprang to life, into root and branch and stem and bud and flower. He had deep faith and belief in Canada and its people; he had love for all its peoples. Standing there in the northland, he may have repeated his Creed, fashioned out of his national experience. It is in his collected Poems:

The world is my country

The human race is my race

The spirit of man is my God

The future of man is my heaven.

Maker and finders know that it is up to us to make our heavens, and our flowerings.
Frank Scott had an abiding faith in the future of man even when regressions and wars seemed to spell doom. He showed us in his daily life the wholeness that goes into the making of a nation's literature, that is a nation's voice. The artists of Canada knew, and know, that in Frank Scott they had the sort of man Flaubert called a "triple thinker." He was a spokesman, defender, literary kinsman, prophet. It seems proper and admirable that McGill libraries have given me today this forum and this opportunity to express publicly the profound feelings I have for Frank Scott and which $I$ share with all who knew him during his long and remarkable life. The libraries are the custodians of our words, our books, our memories. In these libraries, in the future, it will be possible for generations of Canadians yet unborn to discover the radiance of Scott's twentieth century mind and its deepest loyalties to Canada. 